\title{
EFEKTIVITAS PEMBERIAN SUSU KEDELAI DALAM MENGATASI KELUHAN PADA MASA PRE MENOPOUSE DI KLINIK BIDAN MAIHARTI KISARAN BARAT TAHUN 2020
}

\author{
NIKMAH JALILAH RITONGA ${ }^{1}$, YUNI SARTIKA LIMBONG ${ }^{2}$, RIRIS \\ SITORUS $^{3}$, DIAH EVAWANNA ANUHGERA ${ }^{4}$, DEDE MAI SAROH ${ }^{5}$ \\ 1,2,3,4,5 Fakultas Kebidanan Institut Kesehatan Medistra Lubuk Pakam \\ Jl.Sudirman No.38 Lubuk Pakam \\ E-mail : ritonganikmah@yahoo.com
}

DOI $10.35451 /$ jkk.v3i2.590

\begin{abstract}
Pre menopause is a physiological condition characterized by irregular menstruation. Symptoms that often arise such as hot flush, night sweats, restlessness, easy fatigue, pain during intercourse. Overcoming complaints of pre-menopausal non-pharmacological can be done with soy milk. The purpose of this study was to determine the effectiveness of soymilk in dealing with premenopausal complaints at the Midwife Maiharti Clinic, West Range 2020. This study used a quantitative method, with a quasi-experimental design with a control time series design. The study population was pre-menopausal mothers who experienced pre-menopausal symptoms at the Midwife Maiharti Clinic, West Range. The sample selection used purposive sampling as many as 18 people, 9 people were given intervention and 9 people as controls. The results of the study using Wilcoxon sign rank test obtained results for groups that were given pre and post $p$-value interventions $0.002<0.05$. The results of the study using Wilcoxon sign rank test obtained results for the control p-value $0.009<0.05$. The conclusion is that there are differences in the two groups after being given soy milk in dealing with pre-menopausal complaints.
\end{abstract}

Keywords: Soymilk, Pre Menopuse Complaints

\section{Pendahuluan}

Berdasarkan data yang di peroleh dari World Health Organization (WHO) pada tahun 2015, total populasi wanita yang mengalami pre menopause di seluruh dunia mencapai 894 juta orang. Di Asia menurut WHO pada tahun 2025 jumlah wanita yang memasuki masa pre menopause akan melonjak dari 107 juta jiwa akan menjadi 373 juta jiwa dan diperkirakan pada tahun 2030 mendatang jumlah perempuan di dunia yang memasuki masa fase pre menopause akan mencapai 1,2 milyar orang. Artinya sebanyak 1,2 milyar perempuan akan memasuki usia 50 tahun.
Berdasarkan Kemenkes pada tahun 2017, jumlah penduduk wanita di Indonesia yang akan memasuki masa pre menopause sekitar 8.304.021 orang. Berdasarkan data Dinkes Provinsi Lampung pada tahun 2016, jumlah penduduk perempuan yang mengalami masa pre menopause sebanyak 437.050 orang.Berdasarkan data Dinkes Kabupaten Lampung Utara pada tahun 2017, jumlah wanita pre menopause sekitar 197.838 orang.

Wanita di Indonesia memasuki masa pre menopause saat ini sebanyak $7,4 \%$ dari populasi. Jumlah tersebut diperkirakan menjadi $11 \%$ pada 2005 , kemudian naik lagi sebesar $14 \%$ pada tahun 2015(Badan Pusat Statistik, 
2015). Pada Simposium Nasional Perkumpulan Menopouse Indonesia (PERMI) di Jakarta pada tanggal $21-22$ April 2017, dikemukakan lima gejala utama yang dialami dalam mengahadapi masa pre menopause seperti nyeri otot atau sendi $(77,7 \%)$, rasa letih dan hilang energy $(68,7 \%)$, kehilangan nafsu seksual (61,3\%), kerutan di kulit $(60 \%)$, hot flushes $(29,5 \%)$.

Pre menopause adalah masa peralihan dari masa subur menuju masa tidak adanya pembuahan (Anovulation), yang ditandai dengan menurunnya kadar hormon estrogen dari ovarium yang sangat berperan dalam hal reproduksi dan seksualitas. Sebagian besar wanita akan mengalami gejala pre menopause pada usia 40-an dan puncaknya tercapai pada usia 50 tahun, dimana terjadinya masa menopause. Pada masa menopause ini wanita sudah tidak megalami menstruasi lagi (Proverawati, 2019)

Keluhan pre menopause adalah tanda dan gejala yang di alami wanita pada masa pre menopause. Gejala yang timbul karena terjadinya perubahanperubahan yang dialami oleh wanita pre menopause karena menurunnya hormon estrogen di dalam tubuh ( Mulyani, 2019).

Keluhan yang dialami akan sangat serius jika tidak ditangani dengan baik karena dapat menimbulkan perubahan yang menyebabkan kecemasan pada wanita. Kecemasan pada wanita ini diakibatkan karena perubahaan hormon dalam tubuh yang sering kali mempengaruhi keadaan psikis seorang wanita, keadaan psikis seorang wanita sangat sensitive terhadap emosional yang sangat mempengaruhi kehidupan keluarga dan sosialnya ( Proverawati, 2019).

Hormon merupakan pembawa pesan melalu system peredaran darah yang akan mempengaruhi organ yang ada di seluruh tubuh. Hormon estrogen bertanggung jawab atau juga ikut terlibat dalam memperthankan suhu tubuh.Hormon estrogen merupakan paying pelindung bagi wanita dan dapat melindungi dari berbagai penyakit.Kadar hormon estrogen dalam tubuh wanita relative tinggi sebelum masa pre menopause, sehingga pembuluh darah tidak mudah mengeras dan lemak darah tidak mudah naik. Akan berlainan ketika memasuki masa pre menopause, kadar hormon estrogen menurun sehingga kehilangan pelindung terhadap penyakit. Sehingga muncul berbagai keluhan pada masa pre menopause (Proverawati, 2019).

Sejauh ini terapi telah dilakukan berbagai hal untuk mengatasi keluhan pada masa menopouse pada wanita antara lain pemberian pendidikan kesehatan tentang masa pre menopause sehingga secara psikologi wanita yang mengalami masa pre menopause telah siap mengalami fase menopause, olahraga, pola istirahat yang cukup, pemenuhan gizi, serta terapi hormonal untuk menstabilkan hormone estrogen dalam tubuh (Khunty \& Sri, 2014).

Berdasarkan hasil penelitian yang dilakukan oleh Hesti dan Ety pada tahun 2016 menyatakan bahwa fitoestrogen memiliki struktur dan fungsi yang sama seperti estrogen. Fitoestrogen dapat berikatan dengan reseptor estrogen sehingga fitoestrogen dapat mengatasi sensasi terbakar, mempertebal endometrium, meningkatkan elastisitas dan menurunkan $\mathrm{PH}$ vagina, meningkatkan kepadatan tulang, menghambat aterosklerosis, dan meningkatkan fungsi kerja otak.

Berdasarkan hasil penelitian Kunthy dan Sri pada tahun 2014 menyatakan bahwa terdapat pengaruh konsumsi susu kedelai terhadap keluhan menopause, hasil analisis analisis $P$ value $<0,05$, Ho ditolak, sehingga uji statistik menunjukan adanya pengaruh yang signifikan. Mengkonsumsi susu kedelai secara rutin untuk mengatasi keluhan menopause yang dialaminya.

Kandungan yang terdapat di dalam susu kedelai adalah Fitroestrogen merupakan kelompok tanaman seperti kacang-kacangan, biji-bijian, sayusayuran, dan buah-buahan yang memiliki sifat menyerupai hormone estrogen. Fitoestrogen diketahui juga memiliki potensi sebagai alternative terapi sulih hormone untuk mengurangi 
gejala pre menopause seperti hot flush yang diakibatkan berkurangnya hormone estrogen di dalan tubuh (Ety\& Hesti, 2016).

Susu kedelai dikonsumsi pada jam 19.00 dan jam 04.30. 1 gram kacang kedelai mengandung $3,5 \mathrm{mg}$ isoflavon, setiap hari wanita premenopouse membutuhkan 15-30 gram untuk memenuhi kekurangan hormone estrogen di dalam tubuh, dapat terpenuhi dengan mengkonsumsi susu kedelai sebanyak $250 \mathrm{ml}$ setiap hari. Konsumsi susu kedelai setiap hari selama 2 minggu agar tubuh dapat melakukan adaptasi terhadap kandungan susu kedelai yang hampir mirip dengan hormon estrogen, untuk hasil yang lebih baik.

Berdasarkan studi pendahuluan yang telah dilakukan di Klinik Bidan Maiharti Kisaran Barat dari data yang saya dapatkan 33 pasien pre menopause yang datang berkunjung ke Klinik Bidan Maiharti terdapat 24 yang mengalami keluhan premenopouse, seperti panas di daerah wajah, dada, dan leher, jantung yang berdebar debar, susah tidur, gelisah, emosi yang tidak terkontrol, dan berkeringat di malam hari.

\section{METODE}

Penelitian ini menggunakan metode kuantitatif, dengan desain quasi eksperiment (eksperimen semu).Pada desain ini peneliti membandingkan nilai pretest yaitu sebelum dilakukan intervensi dan nilai post test yaitu setelah dilakukan intervensi dengan menggunakan kelompok pembanding. Data yang digunakan di dalam penelitian ini adalah menggunakan data primer dan data sekunder.Analisa data dilakukan dengan uji statistik Paired $T$ Test.

Populasi penelitian ini adalah wanita masa pre menopause yang mengalami keluhan pre menopuse di Klinik Bidan Maiharti Kelurahan Sidomukti Kecamatan Kisaran Barat Kabupaten Asahan berjumlah 10orang berdasarkan dari bulan Desember - Februari.Teknik pengambilan sampel dalam penelitian ini adalah purposive sampling yaitu teknik penentuan sampel berdasarkan pertimbangan peneliti, berdasarkan kriteria inklusi dan ekslusi.Untuk menentukan jumlah sampel dalam penelitian ini digunakan perhitungan rumus Lameshow.Jadi besar sampel yang didapatkan dari rumus di atas adalah 9 orang sebagai kelompok intervensi dan 9 orang sebagai kelompok kontrol.

Tempat penelitian ini dilakukan di Klinik Bidan Maiharti Kisaran Barat.Waktu penelitian dimulai dari pengajuan judul sampai dengan sidang hasil dimulai dari bulan Januari sampai dengan bulan Mei 2020.

\section{HASIL}

Tabel 1 Karakteristik Ibu Pre Menopouse Pada Kelompok Eksperimen Di Klinik Bidan Maiharti Kisaran Barat Tahun 2020

\begin{tabular}{ccrc}
\hline No & Karakteristik & $\mathrm{f}$ & $(\%)$ \\
\hline 1 & \multicolumn{3}{c}{ UMUR } \\
& 43 & 1 & $11,1 \%$ \\
& 45 & 1 & $11,1 \%$ \\
& 48 & 2 & $22,2 \%$ \\
& 50 & 5 & $55,6 \%$ \\
\cline { 2 - 4 } 2 & Total & 9 & $100 \%$ \\
\cline { 2 - 4 } & SD & 2 & $22,2 \%$ \\
& SMP & 1 & $11,1 \%$ \\
& SMA & 5 & $55,6 \%$ \\
& SARJANA & 1 & $11,1 \%$ \\
\hline Total & 9 & $100 \%$ \\
\hline \multicolumn{3}{c}{ PEKERJAAN } \\
IRT & 5 & $55,6 \%$ \\
& 2 & $22,2 \%$ \\
& WIRASWASTA & 2 & $11,1 \%$ \\
& WIRAUSAHA & 1 & $11,1 \%$ \\
\hline & PNS & 1 & $100 \%$ \\
\hline & Total & 9 &
\end{tabular}

Tabel 2 Karakteristik Ibu Pre Menopouse Pada Kelompok Kontrol Di Klinik Bidan Maiharti Kisaran Barat Tahun 2020

\begin{tabular}{cccc}
\hline No & Karakteristik & f & $(\%)$ \\
\hline 1 & & UMUR & \\
& 45 & 2 & $22,2 \%$ \\
& 48 & 2 & $22,2 \%$ \\
& 50 & 5 & $55,6 \%$ \\
\cline { 2 - 4 } 2 & Total & 9 & $100 \%$ \\
\cline { 2 - 4 } 2 & PENDIDIKAN & \\
& SD & 2 & $22,2 \%$ \\
& SMP & 2 & $22,2 \%$ \\
& SMA & 5 & $55,6 \%$ \\
\hline
\end{tabular}


Received: 08 Februari 2021 :: Accepted: 207 April 2021 :: Published: 30 April 2021

\begin{tabular}{cccc}
\hline & Total & 9 & $100 \%$ \\
\cline { 2 - 4 } & & PEKERJAAN \\
IRT & 5 & $55,6 \%$ \\
Wiraswasta & 3 & $33,3 \%$ \\
Wirausaha & 1 & $11,1 \%$ \\
\hline Total & 9 & $100 \%$ \\
\hline
\end{tabular}

Tabel 3 Distribusi Frekuensi Keluhan Pada Ibu Pre Menopouse Sebelum, Sesudah, dan pada kelompok Kontrol di Klinik Bidan Maiharti Kisaran Barat Tahun 2020

\begin{tabular}{|c|c|c|c|c|c|c|c|}
\hline \multirow[t]{2}{*}{ No } & \multirow[t]{2}{*}{ Kategori } & \multicolumn{2}{|c|}{ Pretest } & \multicolumn{2}{|c|}{ Postest } & \multicolumn{2}{|c|}{ Kontrol } \\
\hline & & $\mathbf{F}$ & $(\%)$ & $\mathbf{F}$ & $(\%)$ & $\mathbf{F}$ & $(\%)$ \\
\hline 1 & Ringan & 1 & $11,1 \%$ & 6 & $66,7 \%$ & 2 & $\begin{array}{c}22,2 \\
\%\end{array}$ \\
\hline 2 & Sedang & 3 & $33,3 \%$ & 3 & $33,3 \%$ & 5 & $\begin{array}{c}55,6 \\
\%\end{array}$ \\
\hline 3 & Berat & 5 & $55,6 \%$ & & & 2 & $\begin{array}{c}22,2 \\
\%\end{array}$ \\
\hline & Total & 9 & $100 \%$ & 9 & $100 \%$ & 9 & $\begin{array}{c}100 \\
\%\end{array}$ \\
\hline
\end{tabular}

Berdasarkan table diatas $F$ (Frekuensi) dan \% (Persen), terlihat dari tabel pretest mayoritas keluhan berat sebanyak 5 orang dan minoritas keluhan ringan sebanyak 1 orang. Tabel postest sebanyak 6 orang dan minoritas keluhan sedang sebanyak 3 orang. Tebel kontrol mayoritas keluhan sedang sebanyak 5 orang.

Tabel 4 Pengaruh Pemberian Susu Kedelai Terhadap Keluhan Sebelum dan Sesudah Diberikan Intervensi $\mathrm{Di}$ Klinik Bidan Maiharti Kisaran Barat Tahun 2020 terlihat mayoritas keluhan ringan

rata rata keluhan sesudah diberikan susu kedelai pada ibu premenopouse sebesar 2,22. Hal ini dapat disimpulkan bahwa susudah diberikan susu kedelai responden mengalami efek penurunan keluhan pada masa pre menopause sebesar 1,34poin. Hal uji statistic ini menggunakan uji wilcoxom signrank test di dapatkan $p$-value 0,002 < 0,05. Maka $\mathrm{H}_{0}$ di tolak artinya ada perbedaan sebelum dan sesudah pemberian susu kedelai terhadap keluhan pada ibu pre menopause di Klinik Bidan Maiharti Kisaran Barat Tahun 2020.

Tabel 5

Pengaruh Pemberian Susu Kedelai Terhadap Keluhan Sebelum dan Sesudah Diberikan Intervensi Di Klinik Bidan Maiharti Kisaran Barat Tahun 2020

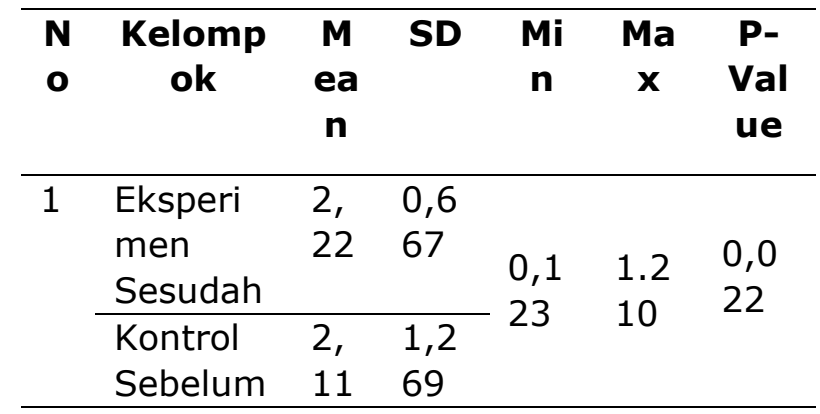

Berdasarkan tabel di atas bahwa ratarata keluhan sesudah diberikan susu kedelai pada ibu pre menopause sebesar 2,22 dan untuk kelompok control (pembanding) sebesar 2,11. Hal ini dapat disimpulkan bahwa sesudah diberian susu kedelai mengalami efek penurunan keluhan pada masa pre menopause sebesar 0,11 poin. Hal uji statistic ini menggunakan uji wilcoxom signrank test di dapatkan p-value $0,022<0,05$. Maka $\mathrm{H}_{0}$ di tolak artinya ada perbedaan kelompok kontrol dengan kelompok sesudah dilakukan pemberian susu kedelai terhadap keluhan pada ibu pre menopause di

1 Eksperimen 3,56 0,726 Sebelum

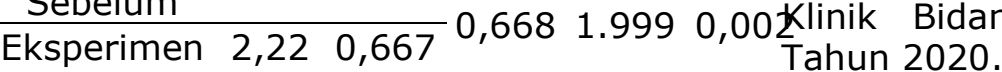

Sesudah

Berdasarkan tabel di atas dapat di lihat, bahwa rata rata keluhan sebelum diberikan susu kedelai pada ibu pre menopause sebesar 3,56, sedangkan 


\section{PEMBAHASAN}

\subsection{Intensitas keluhan pada ibu pre menopause sebelum dilakukan pemberian susu kedelai}

Pre menopause yaitu satu atau dua tahun segera sebelum menopause atau pada semua periode reproduksi sebelum masa menopause. Gejala pre menopause akibat menurunnya kadar estrogen tersebut sering menimbulkan gejala yang sangat mengganggu aktivitas kehidupan para wanita. Masalah yang muncul termasuk hilangnya kesuburan, pada menjelang menopause.Gejala menjadi sangat serius jika tidak ditangani karena dapat menimbulkan perubahan yang menyebabkan kecemasan pada wanita. Masalah yang timbul akibat pre menopause ini disebut dengan sindrom pre menopause, gejala yang sering timbul seperti hot flush, berkeringat malam hari, gelisah, mudah capek, rasa sakit saat berhubungan

Berdasarkan penelitian yang telah dilakukan 55,6\% responden mengalami keluhan berat bahwa separuh dari responden mengalami keluhan pre menopause kategori berat, 33,3\% mengalami keluhan sedang, dan $11,1 \%$ mengalami keluhan ringan. Keluhan pada ibu pre menopause banyak mengalami keluhan berat, karena keluhan pada ibu pre menopause dapat mengganggu aktivitas pada ibu karena mengalami gejala yang sering timbul seperti hot flush, berkeringat malam hari, gelisah, mudah capek, rasa sakit saat berhubungan.

Jika dilihat dari pilihan kategori keluhan yang dirasakan oleh ibu pre menopause diketahui bahwa keluhan somatik 2 orang mengalami keluhan ringan, 5 orang mengalami keluhan sedang, dan 2 orang mengalami keluhan berat. Keluhan psikologi adalah 4 orang mengalami keluhan sedang dan 5 orang mengalami keluhan berat.Keluhan urogenital adalah 4 orang mengalami keluhan sedang dan 5 orang mengalami keluhan berat. Untuk keluhan total 6 orang mengalami keluhan berat, 2 orang mengalami keluhan sedang, dan 1 orang mengalami keluhan ringan. Skala nyeri dari keluhan pre menopause yang di dapat mean 3,56 dan standard deviasi 0,726. Hal ini menunjukan bahwa pemilihan skala nyeri pada setiap orang berbeda.

Menurut Rahmah (2018), bahwa skala nyeri yang di dapat sebelum diberikan susu kedelai berdasarkan Menopouse Rating Scale (MRS) sejumlah 24 orang dengan mean (nilai rata-rata) 11,26 dan standard devisiasi (simpangan baku) 5,848. Hal ini terjadi akibat penurunan hormone estrogen pada saat pre menopouse sehingga ibu mengalami keluhan pada masa pre menopause gejala yang sering timbul seperti hot flush, berkeringat malam hari, gelisah, mudah capek, rasa sakit saat berhubungan.

Keluhan yang dialami pada masa pre menopause adalah hot flushes (semburan panas dari dada hingga bagian wajah), night sweat (berkeringat di malam hari), dryness vaginal (kekeringan vagina), penurunan daya ingat, insomnia (susah tidur), depresi (rasa cemas), fatigue (mudah capek), penurunan libido, drypareunia (rasa sakit saat berhubungan seksual), pusing, dan incontinence urinary (sering buang air kecil) ( Proverawati, 2019).

\subsection{Intensitas keluhan pada ibu pre menopause sesudah dilakukan pemberian susu kedelai}

Hasil dari penelitian ini adalah bahwa terjadi penurunan intensitas keluhan pada ibu pre menopause setelah diberikan susu kedelai. Hal ini membuktikan bahwa pemberian susu kedelai dapat memberikan efek menurunkan keluhan pada ibu masa pre menopause. Berdasarkan penelitian yang telah dilakukan $66,7 \%$ mengalami keluhan ringan dan $33,3 \%$ mengalami keluhan sedang.

Hal ini digambarkan bahwa adanya perubahan keluhan pada ibu masa pre menopause sesudah mengkonsumsi susu kedelai. Karena jika dilihat dari pilihan kategori keluhan yang dirasakan oleh ibu pre menopause diketahui bahwa keluhan somatik yang mengalami keluhan ringan 8 orang dan keluhan sedang sebanyak 1 orang.Pada keluhan psikologi terdapat keluhan sedang sebanyak 9 orang.Pada keluhan urologi terdapat keluhan ringan 7 orang 
dan keluhan sedang sebanyak 2 orang. Dan keluhan total sebanyak keluhan ringan sebanyak 6 orang dan keluhan sedang sebanyak 3 orang. Jika dilihat dari sebelum dan sesudah terdapat perubahan keluhan pada ibu pre menopause.Ramuan yang diberikan mampu mengurangi keluhan pada ibu masa pre menopause sehingga mereka dapat melanjutkan aktivitas sehari-hari.

\subsection{Intensitas keluhan pada ibu pre menopause pada kelompok kontrol dilakukan pemberian konseling}

Berdasarkan penelitian yang telah dilakukan $66,7 \%$ responden mengalami keluhan ringan bahwa separuh dari responden mengalami keluhan pre menopause kategori ringan, $11,1 \%$ mengalami keluhan sedang, dan 22,2\% mengalami keluhan berat. Keluhan pada ibu pre menopause banyak mengalami keluhan ringan, karena pada ibu pre menopause sudah diberikan konseling tentang keluhan pada masa pre menopause.

Jika dilihat dari pilihan kategori keluhan yang dirasakan oleh ibu pre menopause diketahui bahwa keluhan somatik 6 orang mengalami keluhan ringan, 2 orang mengalami keluhan sedang, dan 1 orang mengalami keluhan berat. Keluhan psikologi adalah 7 orang mengalami keluhan sedang dan 2 orang mengalami keluhan berat.Keluhan urogenital adalah 6 orang mengalami keluhan ringan dan 3 orang mengalami keluhan berat. Untuk keluhan total 6 orang mengalami keluhan berat, 1 orang mengalami keluhan sedang, dan 2 orang mengalami keluhan ringan.

\subsection{Efektivitas Pemberian Susu Kedelai Dalam Mengatasi Keluhan Pada Masa Pre Menopouse}

Hasil penelitian menunjukan bahwa di dapatkan $p$-value 0,002 < 0,05. Maka $\mathrm{H}_{0}$ di tolak artinya ada perbedaan sebelum dan sesudah pemberian susu kedelai terhadap keluhan pada ibu pre menopause di Klinik Bidan Maiharti Kisaran Barat Tahun 2020.

Hasil penelitian ini sesuai dengan Rahmah (2018), bahwa setelah dilakukan uji statistic di dapat hasil $p$ value $0,004<0,05$. Maka dapat disimpulkan bahwa $\mathrm{H}_{0}$ di tolak artinya ada perbedaan sebelum dan sesudah pemberian susu kedelai terhadap keluhan pada ibu pre menopause.

Hasil penelitian ini sesuai dengan Khunty \& Sri (2014) bahwa setelah dilakukan uji statistic di dapat hasil $p$ value $0,001<0,05$, maka dapat disimpulkan bahwa ada pengaruh konsumsi susu kedelai terhadap keluhan menopause. Konsumsi susu kedelai secara rutin menyebabkan tetap adanya hormon ekstrogen dalam tubuh wanita menopause sehingga ibu tidak lagi mengalami keluhan menopause yang pada dasarnya disebabkan karena penurunan produksi hormon ekstrogen dalam tubuh. Semakin lama jangka waktu mengkonsumsi kedelai, efeknya akan semakin baik. Manfaat kedelai juga masih dapat diperoleh meski wanita tersebut sudah berusia 50 tahun dan belum pernah mengkonsumsi kedelai sebelumnya.

Hasil penelitian ini sesuai dengan (Hetty \& Nelfi, 2018) Hal ini sesuai dengan hasil penelitian memakai program SPSS uji Wilcoxon didapatkan hasil analisis bivariat dengan membandingkan nilai pre dan posttest menunjukkan nilai $\rho=0,001 \quad(\rho<0,05)$ sehingga dapat diambil kesimpulan pemberian susu kedelai berpengaruh terhadap penurunan gejala dalam keluhan pada ibu di masa pre menopousenya.

Berdasarkan kelompok sesudah dengan kelompok pembanding (kontrol) berdasarkan uji statistic ini menggunakan uji wilcoxom signrank test di dapatkan $p$-value 0,022<0,05. Maka $\mathrm{H}_{0}$ di tolak artinya ada perbedaan kelompok kontrol dengan kelompok sesudah pemberian susu kedelai terhadap keluhan pada ibu pre menopause di Klinik Bidan Maiharti Kisaran Barat Tahun 2020.

Berdasarkan asumsi peneliti keluhan pre menopause disebabkan karena penurunan hormone estrogen mengakibatkan gejala yang sering timbul seperti hot flush, berkeringat malam hari, gelisah, mudah capek, rasa sakit saat berhubungan. Keluhan ini merupakan suatu ketidaknyamanan yag dialami ibu-ibu pada masa pre 
menopause yang menyebabkan terganggunya aktivitas sehari hari dan megganggu waktu istirahat.

Mengatasi keluhan pada ibu masa pre menopause dapat dilakukan dengan berbagai cara baik secara farmakologi dan nonfarmakologi. Bangsa Indonesia telah lama mengenal dan menggunkan tanaman berkhasiat obat salah satunya dapam upaya menanggulangi masalah keseahatan. Pengobatan herbal yang mengurangi keluhan pada saat pre menopause salah satunya adalah susu kedelai. Susu kedelai mengandung fitoestrogen yang memiliki kandungan isovlafon yang mempunyai kandungan hampir sama dengan estrogen sehingga dapat menurunkan keluhan pada ibu masa pre menopause dengan cara iovlafon akan mengikat reseptor estrogen yang berada di hipotalamus, menstimulasi termoregulator, menyebabkan vasodilatasi aliran darah perifer, menghambat penguapan, sehingga pelepasan berkurang dan dapat mengatasi keluahan pre menopouse.

\section{KESIMPULAN}

Susu kedelai efektif sebagai akternatif penanganan keluhan pada masa Premenopouse.

\section{DAFTAR PUSTAKA}

Adriani, M. dan Wirjatmadi, B. (2016). Peranan Gizi Dalam Siklus Kehidupan. Jakarta : Kencana

Anggrahini, K dan Handayani, S (2014).Pengaruh Konsumsi Susu Kedelai Terhadap Keluhan Menopouse. Jawa Tengah : http://ejurnal.stikeseub.ac.id. Di Akses Pada : 21 Januari 2020

Ariyanti, H dan Apriliana, E. (2016). Pengaruh Fitoestrogen Terhadap Gejala Menopouse. Lampung :http://jurnal.fk.unila.ac.id.

Akses Pada : 21 Januari 2020

Heinemann, L.AJ, Potthoff P, Schneider HP. (2003). International versions of theMenopouse Rating Scale (MRS).https://www.ncbi.nlm.nih. gov/pmc/articles/PMC183844/. Di Akses Pada : 8 April 2020.
Khulasoh.(2018). Penerapan Konsumsi Susu Kedelai Untuk Mengurangi Hot Flush Pada Wanita Pre Menopouse. Jawa Tengah :http://elib.stikesmuhgombong.ac id. Di Akses Pada : 21 Januari 2020

Lubis, N.J. (2016). Psikologi Kespro Wanita Dan Perkembangan Reproduksinya. Jakarta : Kencana

Maita, L. ( 2019 ). Gizi Kesehatan Pada Masa Reproduksi. Yogyakarta : Deepublish.

Marmi.(2017). Gizi Dalam Kesehatan Reproduksi.Yogyakarta : Pustaka Pelajar.

Mulyani, N.S. (2019). Menopouse Akhir Siklus Menstruasi Pada Wanita Di Usia Pertengahan. Yogyakarta : Nuha Medika.

Riyanto, A. (2019). Aplikasi Metodologi Penelitian Kesehatan. Yogyakarta : Nuha Medika.

Salim, R.A. dan Enterprise, F. (2015). (Un) Complicated Perimenopause.Jakarta : PT. Elex Media Komputindo.

Sihotang, H.M dan Sarlis, N. (2018).Efektifitas Susu Kedelai Terhadap Penurunan Gejala Hot Flush Pada Wanita Klimakterium. Pekan Baru :http://jurnal.mitrahusada.ac.id. Di Akses Pada : 17 Januari 2020.

Suparni, I.E dan Astutik, R.Y. (2016).Menopause Masalah Dan Penanganannya.Yogyakarta Deepublish

Proverawati, A. (2019). Menopause Dan Sindrome

Premenopause.Yogyakarta : Nuha Medika.

Wardiah, A. Dkk. (2019). Pengaruh Pendidikan Kesehatan Tentang Menopouse Terhadap Pengetahuan Ibu Premenopouse. Lampung Utara :http://ejurnalmalahayati.ac.id. Di Akses Pada : 19 Maret 2020

Yolanda, KR. (2017). Identifikasi Keluhan Yang Terjadi Pada Wanita Menopouse. Sulawesi Tenggara :http://repository.poltekkeskdi.ac.id. Di Akses Pada : 07 April 2020 
Zolekhah, D. dan Sholihah, N.R. (2018).Tingkat Keluhan Berdasarkan Menopouse Rating Scale Pada Ibu Menopouse.Yogyakarta :http://journal.ibrahimy.ac.id. Di Akses Pada : 20 Maret 2020

Zahra, F. dan Sopiatun, R. (2018). Pengaruh Penyuluhan Terhadap Tingkat Kecemasan Dalam Menghadapi Premenopause. Jawa Barat

:http://journalmu.poltekkesmataram.ac.id. Di Akses Pada : 19 